\title{
The Effect of Bank Specific Factors on Financial Performance of Commercial Banks in Kenya.
}

\author{
Caroline Wangu Muriuki \\ Egerton University \\ Dr. Fredrick Kalui $(\mathrm{PhD})$ \\ Department of Accounting \& Finance, Egerton University, P.o.Box 536, Egerton \\ Nyang'aya,R.O.Akuno \\ Department of Agricuture Economics \& Agribusiness, Egerton University, P.o.Box 536, Egerton
}

\begin{abstract}
The main goal of many banks is to grow and sustain growth in its financial performance. Internal factors are viewed as critical drivers for bank financial performance. The main goal of this study was to investigate the effect of bank specific factors on financial performance of commercial banks in Kenya. Various studies indicate divergent views on the effect of bank specific on commercial banks financial performance. There is lack of consensus on the effect of bank specific factors on bank financial performance. Different researchers have used different models and assumed different variables. The main objective of this study was to assess the effect of bank specific factors on the financial performance of commercial banks in Kenya. The Findings of the study should help understand the effect of bank specific factors on financial performance of commercial banks in Kenya. In light of the different views that appear in some studies the results will be useful to investors, management, auditors, financial analyst and researchers. The population of this study comprised of all the forty five(45) commercial banks in Kenya licensed by the Central Bank of Kenya (CBK) .The study used Panel data covering a period of eleven years from 2007 to 2017. The data was collected from CBK published financial annual supervisory reports for the 45 commercial banks listed by Central bank of Kenya and the Kenya National Bureau of Statistics periodic reports. The study used Correlation and multiple linear regression analysis to analyze the data. The researcher used SPSS software to assist in analyzing the data. The study established that bank specific accounted for $89.3 \%$ financial performance of commercial banks in Kenya $\left(\mathrm{R}^{2}=0.893\right)$. This point out that bank specific strongly predicts financial performance of listed commercial banks in Kenya. Therefore, bank specific have a statistical positive significant effect on financial performance of commercial banks in Kenya. The study recommends further research on other bank specific together with macroeconomic factors to determine whether they have a significant positive effect on financial performance of commercial banks in Kenya or not.
\end{abstract}

Key wards: Bank Specific Factors, Financial Performance.

DOI: $10.7176 /$ RJFA/10-20-14

Publication date:October $31^{\text {st }} 2019$

\section{Background of the study}

According to Collins et.al, (2011) financial institutions facilitate mobilization of savings, diversification and pooling of risks and allocation of resources in the economy. Banks, as financial institutions, play a vital role for bringing financial stability and economic growth through their expected contribution by mobilizing financial resources across the economy (Masood and Ashraf, 2012). The role is more important for the developing economies under developed capital market (Felix Ayadi et al., 2008; Zhang et al., 2013). A sound and profitable banking system is better able to improve financial system stability and economic growth as it makes the economy more endurable to negative and external shocks (Athanasoglou et al., 2008), on the other hand, insolvency of the system leads to economic crisis (Chaplinska, 2012; Fang et al., 2014; Fu et al., 2014).

Moreover, financial performance is considered as precondition for an innovative, productive and efficient banking system (Chen \& Liao, 2011). Therefore, investigation of the determinants of profitability is vital for the growth and stability of the whole economy. Considering the importance of banking performance many studies have been conducted focusing both single country and cross countries., according to Hassan and Bashir (2003) 21 developing countries where Islamic banking has been practiced, Samad (2004) for Bahrain, .

For developing countries, improvements in the banking sector could have significant impact on the allocation of financial resources. Lending by commercial banks involves committing funds into diverse sectors of the economy 
with an expectation of returns inform of interest income. On the other hand, lending is the largest source of credit risk to commercial banks. That's why the banking sector has been singled out for special protection and it is clear why such great emphasis is placed on regulation and supervision of the banking sector (Barth, 2006).

The importance of financial sector in the development of the overall economy of country cannot be underestimated because the banking sector dominates the economic development of a country by mobilizing the savings of general people and channeling those saving towards investment and economic development and growth. Therefore, financial performance of the banking sector has direct impact on overall development and growth of economy. Financial performance is one of the important pointers of industry performance that has major insinuation on sector's activities. Sound and profitable banking sector will be able to hold out negative shocks and act as a safeguard of financial stability (Sologoub, 2006).

\section{Statement of the Problem}

Globally, banking is a rapidly growing industry in the process of economic development. It's crucial to understand the influence of selected bank specific factors and macroeconomic variables on bank financial performance in Kenya. There are many studies done on effect of bank specific on financial performance but they lack consensus. A study by Obamuyi (2013), the determinant of bank profitability in developing economies with a particular interest in Nigeria showed that bank specific factors such as management and increased interest income affect profitability; he also researched on macro factors such as favorable economic factor which showed increased profitability. This study ignored many bank specific factors and only focused on a few.

Previous studies considered short panel data consisting of 5 to 6 years which also might be a contributor to those outcomes. Although the studies explain meaningful analyses at certain levels, the area of bank specific factors effect on financial performance of commercial banks in Kenya need to be further explored for better understanding of their effects for sector planning. Available literature has not fully concentrated on effect of bank specific factors on the bank performance in a developing country like Kenya. Therefore, this study aimed to determine the effect of selected bank specific factors and macroeconomics factors on financial performance of commercial banks in Kenya.

\section{General Objective}

The study aimed at determining the effect bank specific factors on financial performance of commercial banks in Kenya.

\section{Specific Objectives}

i. To determine the effect of capital adequacy on the financial performance of commercial banks in Kenya.

ii. To determine the effect of asset quality on financial performance of commercial banks in Kenya.

iii. To determine the effect of management efficiency on the financial performance of commercial banks in Kenya.

iv. To determine the effect of liquidity management on the financial performance of commercial banks in Kenya.

v. To determine the effect of risk management on the financial performance of commercial banks in Kenya.

\section{Research Hypotheses}

Ho1: There is no significant effect of capital adequacy on financial performance of commercial banks in Kenya. Ho2: There is no significant effect of asset quality on financial performance of commercial banks in Kenya.

Ho3: There is no significant effect of management efficiency on financial performance of commercial banks in Kenya.

Ho4: There is no significant effect of liquidity management on financial performance of commercial banks in Kenya

Ho5: There is no significant effect of risk management on financial performance of commercial banks in Kenya 


\section{Literature Review \\ Theoretical Framework}

\section{Efficiency Structure Theory}

Conversely, the ES theory proposes that enhanced managerial scale efficiency leads to higher concentration and then to higher profitability. This is a clear indication of desirable financial performance of firms especially the commercial banks. Nzongang and Atemnkeng (2006) asserted that the balanced portfolio theory added a different dimension into the study of bank performance. The theory suggests that the portfolio composition of a commercial bank, its profit and the return to shareholders is the result of the decisions made by the management and the overall bank's policy decisions. Therefore, the theories contribute to the conclusion that banks financial performance is influenced by both internal and external factors. According to this study, bank specific factors fall under the internal factors

\section{CAMEL Model}

This study used the CAMEL model of bank performance measurement. The model involves the use of financial ratios in measuring bank performance. Compared to the other models, the CAMEL model is the most popular framework used by regulators for bank performance evaluation ( Sufian \& Habibullah, 2010; Al-Tamimi, 2010; Khrawish, 2011; Kouser \& Saba, 2012). Apart from being the most used method for evaluating bank performance, the CAMEL is also a contemporary model of financial analysis and the most recent innovation in the financial performance evaluation of banks (Sangmi \& Nazir, 2010). The model assesses bank performance based on bank specific factors. These are capital adequacy, asset quality, management efficiency and soundness, earnings and liquidity. The likelihood of bank failure is increased if any of these factors show signs of inadequacy. Financial ratios such as return on assets (ROA) return on equity (ROE), and net interest margin (NIM) form part of the financial ratios that the CAMEL model uses to evaluate performance.

\section{Financial Performance of Commercial Banks}

One way to measure bank performance is by determining the financial performance of the bank. Financial performance is the ability of a bank to make profits by earning more money that exceeds the yearly expenses and taxes every financial year. Financial performance can also be defined as an approach to determine the extent to which the financial goals such as increase in shareholder value, financial performance and cash flows are achieved in a particular period of time On the other hand; liabilities are main expense of the bank through interest paid on deposits and funds borrowed from other institution. Financial performance is an important channel for enterprises and stakeholder to get the performance information (Sun, 2011). The performance evaluation of a commercial bank is usually related to how well the bank can use its asset, shareholders' equities and liabilities, revenues and expenses. The performance evaluation of banks is important for all parties including depositors, investors, bank managers and regulators.

If the earning per expense is positive, then the bank is profitable .Kamande (2012) the bank's assets that attract revenue to the institution include loans to individuals companies and securities the bank holds. The measure of firms performance usually employs the financial ratio method because they provide simple description about the firm's financial performance in comparison with previous periods and helps to improve its performance of management (lin et al., 2005).Moreover, the ratio analysis assists in determining the financial position of the bank compared to other banks..Bank performance can be determined by the return of assets (ROA), return on equity (ROE), capital adequacy ratio (CAR), non-performing loan ratio (NPL), interest expense to total loans (IETTL), net interest margin (NIM), credit to deposit ratio (CDR) the assets such as the loans and securities are utilized by the banks to earn a large portion of the institution's income

\section{Bank Specific Factors}

Haron (2004) identify bank internal factors as bank specific factors which can either be financial factors or nonfinancial factors. Financial variables relate to the decisions which directly involve items in the balance sheet and income statement, while non-financial statement variables are outside the financial statement. Financial statement indicators include bank size, capital ratio, deposits, operational efficiency, risk management, asset quality and liquidity. The non-financial variables include employees, number of branches, customers, ownership, ATM and ownership.

Generally, bank specific factors are internal factors which affect the day to day operation of the bank, and are within scope of management to manipulate. Dang (2011) explain that these factors are also within the scope of the 
bank to observe and control them and they differ from bank to bank. Dang (2011) also explain CAMEL framework is often used by scholars to proxy the bank specific factors. CAMEL stands for Capital Adequacy, Asset Quality, Management Efficiency, and Earnings ability and liquidity. Other factors include capital, size of deposit liabilities, credit portfolio, interest rate policy, labor productivity, and state of information technology, risk level, management quality, bank size and ownership among others (Dang, 2011).

\section{Capital Adequacy and Financial Performance}

Capital is one of the bank specific factors that influence the level of bank performance. Capital is the amount of own fund available to support the bank's business and act as a buffer in case of adverse situation (Athanasoglou et al. 2005). Banks capital creates liquidity for the bank due to the fact that deposits are most fragile and prone to bank runs. Moreover, greater bank capital reduces the chance of distress (Diamond, 2000). However, it is not without drawbacks that it induces weak demand for liability, the cheapest sources of fund Capital adequacy is the level of capital required by the banks to enable them withstand the risks such as credit, market and operational risks they are exposed to in order to absorb the potential loses and protect the bank's debtors. According to Dang (2011), the adequacy of capital is judged on the basis of capital adequacy ratio (CAR). Capital adequacy ratio shows the internal strength of the bank to withstand losses during crisis. Capital adequacy ratio is directly proportional to the resilience of the bank to crisis situations. It has also a direct effect on the financial performance of banks by determining its expansion (Sangmi and Nazir, 2010).

\section{Asset Quality and Financial Performance}

The bank's asset is another bank specific variable that affects the financial performance of a bank. The bank asset includes among others current asset, credit portfolio, fixed asset, and other investments. Often a growing asset (size) related to the age of the bank (Athanasoglou et al., 2005). More often than not the loan of a bank is the major asset that generates the major share of the banks income. The quality of loan portfolio determines the financial performance of banks. The highest risk facing a bank is the losses derived from delinquent loans (Dang, 2011). Thus, nonperforming loan ratios are the best proxies for asset quality. Different types of financial ratios used to study the performances of banks by different scholars. It is the major concern of all commercial banks to keep the amount of nonperforming loans to low level. This is so because high nonperforming loan affects the profitability of the bank. Thus, low nonperforming loans to total loans shows that the good health of the portfolio a bank. The lower the ratio the better the bank performing (Sangmi and Nazir, 2010).

Sufian and Chong (2008) examined the determinants of Philippines banks profitability during the period 19902005 in Philippines banks. The results of the study showed a direct relationship between financial performance and bank-specific factors. Similarly, the empirical results suggested that the bank specific factors including asset quality affects profitability and by extension the financial performance of the banks.

\section{Management Efficiency and Financial Performance}

Management Efficiency is one of the key internal factors that determine the bank profitability. It is represented by different financial ratios like total asset growth, loan growth rate and earnings growth rate. Yet, it is one of the complexes subject to capture with financial ratios. Moreover, operational efficiency in managing the operating expenses is another dimension for management quality. The performance of management is often expressed qualitatively through subjective evaluation of management systems, organizational discipline, control systems, quality of staff, and others. Yet, some financial ratios of the financial statements act as a proxy for management efficiency.

The capability of the management to deploy its resources efficiently, income maximization, reducing operating costs can be measured by financial ratios. One of this ratios used to measure management quality is operating profit to income ratio ( Sangmi and Nazir, 2010). The higher the operating profits to total income (revenue) the more the efficient management is in terms of operational efficiency and income generation. More recently, Masood and Ashraf (2012) also find that operational expense ratio is negatively associated to bank profitability. It implies that cost decisions of a bank management are instrumental in influencing its performance.

\section{Liquidity and Financial Performance}

Liquidity is another factor that determines the level of bank performance. Liquidity refers to the ability of the bank to fulfill its obligations, mainly of depositors. According to Dang (2011) adequate level of liquidity is positively related with bank profitability. Liquidity measures the banks' ability to cater for short term expenses and current liabilities. From the literature if found to be high it means that the bank has an opportunity cost from the excess funds which could be used for investment The most common financial ratios that reflect the liquidity position of a bank according to the above author are customer deposit to total asset and total loan to customer deposits. Other 
scholars use different financial ratio to measure liquidity. For instance, Ilhomovich (2009) used cash to deposit ratio to measure the liquidity level of banks in Malaysia. However, the study conducted in China and Malaysia found that liquidity level of banks has no relationship with the performances of banks (Said and Tumin, 2011).

\section{Risk and Financial Performance}

This is another important determinant of bank profitability. Risk is involved in every banking operation due to its nature. A bank may be failed due to low liquidity and poor assets quality. Therefore, bank risk may be grouped in to credit risk, liquidity risk, Market risk and operational risk. Among others, Athanasoglou et al. (2008) and Masood and Ashraf (2012) find that credit risk affect profitability negatively and significantly. This may imply that the tendency of commercial bank to exposure high risk loan generates more unpaid loan resulting these loan loss produces low profit to the commercial banks. Moreover, Francis (2013) finds liquidity is significantly and negatively related to profitability as higher liquid assets reduce the ability of banks to generate income. On the other hand, Masood and Ashraf (2012) shows that liquidity has no effect or less effect on profitability.

A study done by Athanasoglou et al, (2008) examined the impact of bank specific, industry-specific and macroeconomic factors on bank profitability using an empirical framework that incorporated the traditional Structure-Conduct-Performance (SCP) hypothesis. The research involved Greek banks that were conducted 19852001. The researchers used several independent variables, namely capital, credit risk, productivity, expense management, ownership, inflation and business cycles. The empirical results indicated that capital is significant in explaining bank profitability. The findings also indicated that capital increased the exposure to credit risk and lowers profits for commercial banks.

\section{Conceptual Framework}

Mugenda and Mugenda (2003) said a conceptual framework is a graphical or diagrammatic representation of the relationship between variables in a study it helps the researchers see the proposed relationship easily and quickly. In this study it showed the relationship between the independent variables explanatory (bank specific factors) and dependent (Return on Asset). It assumes a linear relationship between them. In this study the moderating variables were assumed constant.

\section{Independent variable}

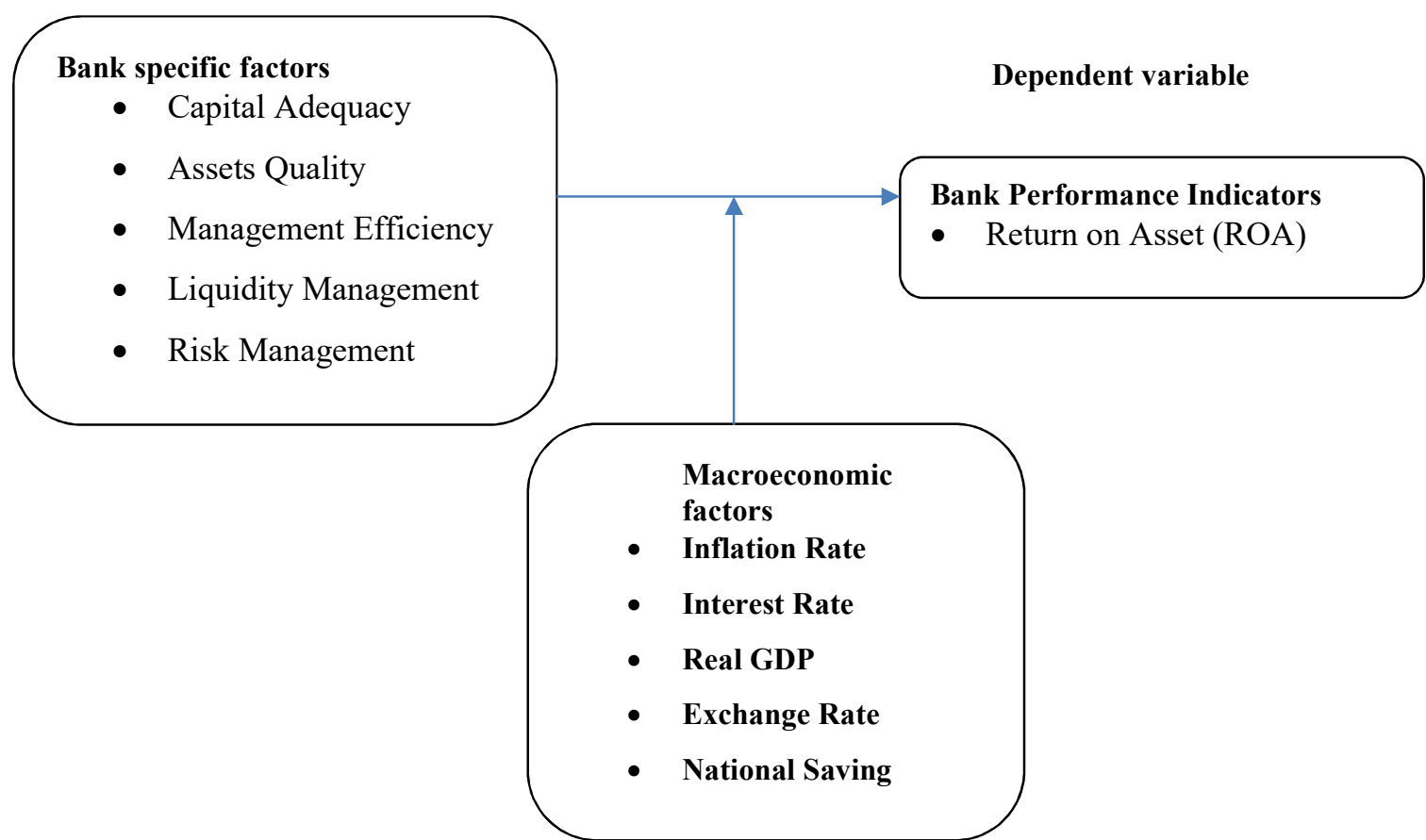

\section{Moderating variable}

Figure 1: Conceptual framework 
Research Methodology

Descriptive research design was used since the data obtained on the elements and the variables was for a given time period. According to Groves (2004) descriptive technique gives accurate information of persons, events or situations.

\section{Target Population}

Flick (2009) defines target population as the entire group of people, events or things that the researcher intends to study. The target population in the study involved all the 45 listed commercial banks in Central Bank of Kenya (2015).The researcher chose the commercial banks because first, they have the widest geographical coverage in Kenya, through their branch network band; secondly they offer both saving and credit services. The research employed census design to all the listed banks. Descriptive research design was used since the data obtained on the elements and the variables was for a given time period. According to Groves (2004) descriptive technique gives accurate information of persons, events or situations.

\section{Data Collection}

The study used secondary data. Panel data was collected from published reports of the central bank of Kenya on the bank audited supervisory annual reports for the eleven years in the study between 2007 and 2017.This period was chosen because it offered current observation; Data which was used to measure financial performance was obtained for the same period of study. The data was sourced using a data collection form

\section{Data Analysis and Presentation}

The study used correlation and multiple regression analysis to measure the variables, this model of analysis examined the simultaneous effects of the independent variables on the dependent variable. Capital adequacy (CAR), Asset Quality (AQ) Management Efficiency (ME), Liquidity Management (LM) and risk management was used as independent variable.

The major dependent variable was operationalized as Return on Asset (ROA). The CAMEL ratios are the popular bank specific factors often used in representing bank specific factors in relation to performance. The CBK also uses CAMEL ratio to evaluate the performances of banks. In this study the data was analyzed using correlation and multiple regression analysis models to test the association between the independent and dependent variables. Multiple regression analysis models was used to measure the effect of changes in the bank specific factors on the financial performance of commercial banks with dependent variable ROA

$\mathrm{ROA}=\mathrm{PBT} /$ Total assets

\section{Regression Model Equation}

The following multiple linear regression models were specified for this study: Multiple Regression Model for selected bank specific factors

$Y=a+\beta_{1} X_{1}+\beta_{2} X_{2}+\beta_{3} X_{3}+\beta_{4} X_{4}+\beta_{5} X_{5}+\varepsilon$

Where $\mathrm{Y}=$ Financial Performance $(\mathrm{ROA})$

$\mathrm{a}=$ Constant

$\beta_{1}-\beta_{5}=$ Régression coefficients

$\mathrm{X}_{1}=$ Capital adequacy

$\mathrm{X}_{2}=$ Asset quality

$\mathrm{X}_{3}=$ Management efficiency

$\mathrm{X}_{4}=$ Liquidity management

$\mathrm{X}_{5}=$ Risk management

$\varepsilon=$ error term

\section{Results and Discussion}

\section{Bank Specific Factors}

The following specific factors were used in the study: Capital adequacy, asset quality, management efficiency, liquidity management and risk management. Table 1 shows the overall descriptive statistics of the all bank specific factors over 11 years of study. 
Table 1: Bank Specific Factors Overall Results

\begin{tabular}{lccccccccc}
\hline & \multicolumn{1}{c}{} & \multicolumn{1}{c}{ M } & \multicolumn{4}{c}{ Skewness } & \multicolumn{2}{c}{ Kurtosis } \\
\hline & 11 & 0.19 & 0.23 & 0.205 & .01269 & 0.815 & 0.687 & 0.254 & 1.334 \\
\hline $\begin{array}{l}\text { adequacy } \\
\text { Asset quality }\end{array}$ & 11 & 0.35 & 0.56 & 0.426 & .06620 & 0.886 & 0.687 & 0.475 & 1.334 \\
$\begin{array}{l}\text { Management } \\
\text { efficiency }\end{array}$ & 11 & 0.42 & 0.65 & 0.575 & .06587 & -1.400 & 0.687 & 3.046 & 1.334 \\
$\begin{array}{l}\text { Liquidity } \\
\text { management }\end{array}$ & 11 & 0.37 & 0.44 & 0.402 & .02821 & 0.303 & 0.687 & -1.761 & 1.334 \\
$\begin{array}{l}\text { Risk } \\
\text { management }\end{array}$ & 11 & 1.08 & 2.74 & 1.670 & .54793 & 1.405 & 0.687 & 0.869 & 1.334 \\
\hline
\end{tabular}

The descriptive results on table 2 that the average capital adequacy is 0.205 with minimum and maximum capital adequacy being 0.19 and 0.23 correspondingly. This point out that the average capital adequacy for the listed commercial banks is $20.5 \%$ which is directly above the regulatory value of $14.5 \%$. The average value of assets quality is 0.426 with minimum and maximum capital adequacy being 0.35 and 0.56 correspondingly. The average Management efficiency was 0.575 with minimum and maximum Management efficiency being 0.42 and 0.65 correspondingly. The average value of Liquidity management is 0.402 with minimum and maximum Liquidity management being 0.37 and 0.44 correspondingly which suggest that the average value of liquidity of the commercial banks listed by central bank of Kenya is $40.2 \%$. The average Management efficiency was 0.575 with minimum and maximum management efficiency being 0.42 and 0.65 correspondingly. This points out that the average value of management efficiency of the commercial banks listed by central bank of Kenya is $57.5 \%$. The average Risk management is 1.670 with minimum and maximum management efficiency being 1.08 and 2.74 congruently. Moreover, the results of the study summaries that the all skewness and kurtosis values were less than 2 which indicates that the data was normally distributed.

Table 2: Bank Specific Factors Year by Year Mean

\begin{tabular}{lccccccccccc}
\hline YEAR\VARIABLE & $\mathbf{2 0 0 7}$ & $\mathbf{2 0 0 8}$ & $\mathbf{2 0 0 9}$ & $\mathbf{2 0 1 0}$ & $\mathbf{2 0 1 1}$ & $\mathbf{2 0 1 2}$ & $\mathbf{2 0 1 3}$ & $\mathbf{2 0 1 4}$ & $\mathbf{2 0 1 5}$ & $\mathbf{2 0 1 6}$ & $\mathbf{2 0 1 7}$ \\
\hline Capital adequacy & 0.19 & 0.20 & 0.21 & 0.22 & 0.20 & 0.23 & 0.21 & 0.20 & 0.19 & 0.20 & 0.19 \\
& & & & & & & & & & & \\
Asset quality & 0.43 & 0.42 & 0.45 & 0.50 & 0.56 & 0.45 & 0.40 & 0.39 & 0.35 & 0.35 & 0.39 \\
$\begin{array}{l}\text { Management } \\
\text { efficiency }\end{array}$ & 0.62 & 0.64 & 0.65 & 0.58 & 0.57 & 0.56 & 0.55 & 0.55 & 0.42 & 0.60 & 0.63 \\
$\begin{array}{l}\text { Liquidity } \\
\text { management }\end{array}$ & 0.46 & 0.37 & 0.40 & 0.44 & 0.37 & 0.43 & 0.39 & 0.38 & 0.38 & 0.42 & 0.44 \\
Risk management & 3.1 & 2.74 & 2.58 & 1.53 & 1.71 & 1.44 & 1.53 & 1.37 & 1.41 & 1.08 & 1.31 \\
\hline
\end{tabular}

Source: CBK annual supervisory reports, 2007-2017

The results in table 2 indicate the average mean per year for selected bank specific factors (Capital adequacy, Asset quality, Management efficiency, Liquidity management, Risk management) from the year 2007 to 2017. 


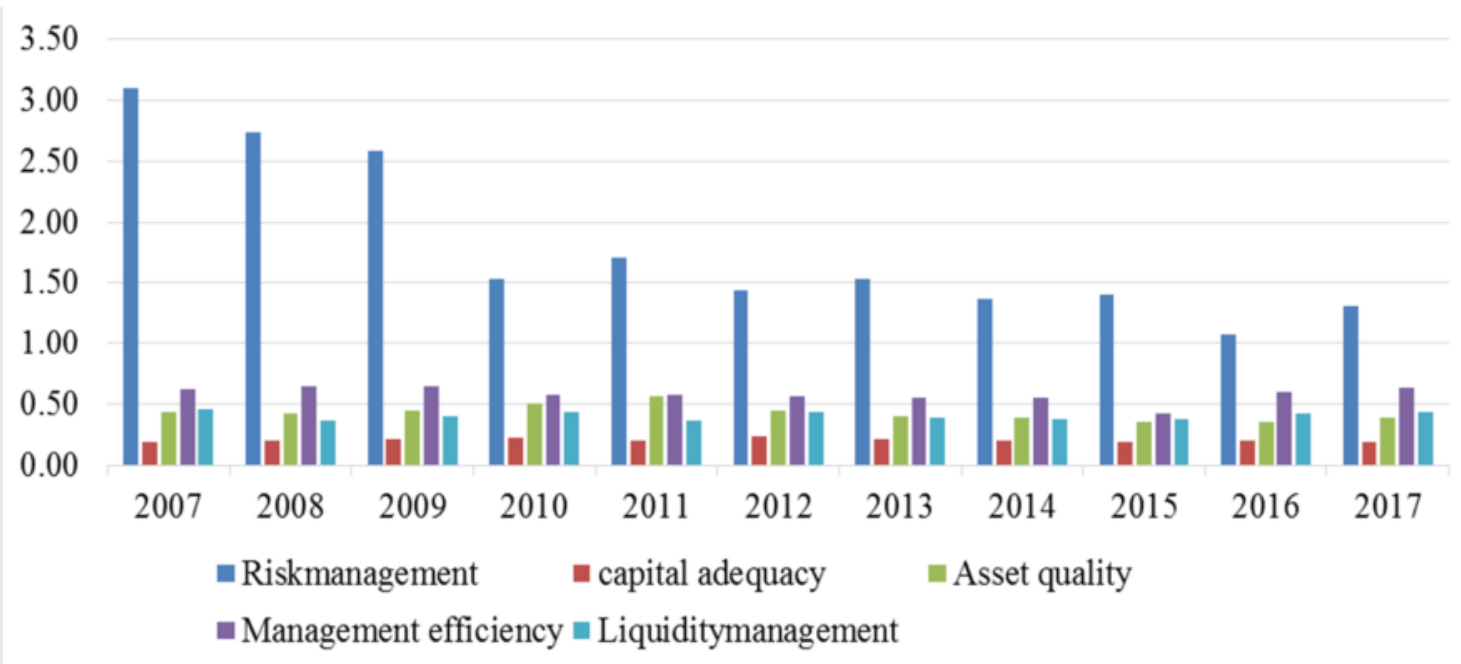

Figure 2: Bank specific factors

Based on the results of the study in figure 2 there was a gradual decline in Risk management from the year 2007 to 2017 compared to capital adequacy which remained almost constant from the year 2007 to 2017 . The results of the study revealed gradual increase of management efficiency from the year 2007 to 2014 then a decline a decline in 2015 followed by an increase in 2016 and 2017 respectively. The listed commercial banks portrayed slow improvement in asset quality and liquidity management.

\section{Bank Performance}

The study used Return on Assets ratio to measure the financial performance of commercial banks in Kenya. Table 3 shows the descriptive statistics of bank performance.

Table 3: Return on Assets

\begin{tabular}{cccccccccc}
\hline & & \multicolumn{1}{c}{ Skewness } & \multicolumn{2}{c}{ Kurtosis } \\
\hline \multirow{2}{*}{ ROA } & $\mathrm{N}$ & Min & Max & Mean & Std. D & Statistic & Std. E & Statistic & Std. E \\
\hline & 11 & 0.030 & 0.050 & 0.036 & 0.008 & \multirow{2}{*}{1.001} & 0.687 & -0.665 & 1.334 \\
\hline
\end{tabular}

The descriptive result on table 3 indicates that the average ROA of the commercial banks is 0.036 with minimum and maximum ROA being 0.03 and 0.5 respectively. This suggests that the average performance in financial terms of listed commercial banks is $3.6 \%$.

Table 4: ROA Year by Year Mean

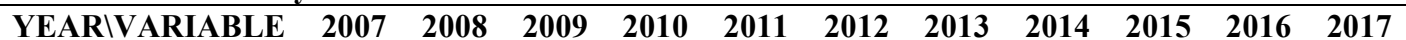

\begin{tabular}{llllllllllll}
\hline ROA & 0.03 & 0.03 & 0.03 & 0.04 & 0.04 & 0.05 & 0.05 & 0.03 & 0.03 & 0.03 & 0.03
\end{tabular}

Source: CBK annual supervisory reports, 2007-2017

The results in table 4 indicate the average mean of ROA per year from the 2007 to 2017 


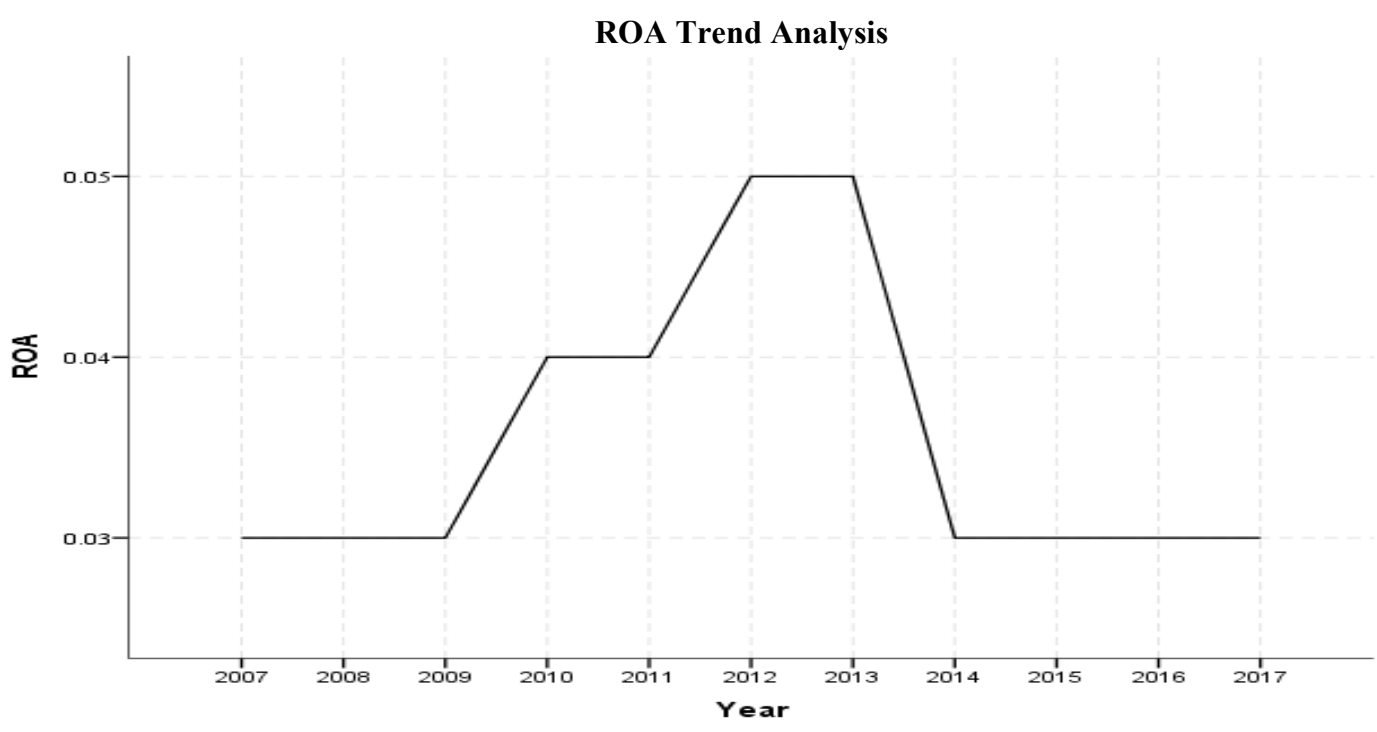

Figure 3: ROA Trend Analysis

Based on the results of the study in figure 3 ROA of listed commercial banks in Kenya portrayed an increasing trend from the year 2007 to 2012 this may be due to the significant reduction of non -performing loans from 5\% to $3.4 \%$ according to CBK supervision report. There is a declining trend from year 2013 to 2014 . This could be attributed to, by venturing new business, market slow down, relaxing of financial controls, increase of market competition, interest capping by central bank poor management of banks and non-effective bank policies. Nevertheless on average the performance of commercial bank is increasing Compared to the financial performance of banks in developing countries the overall financial performance of commercial banks in the country is good (Flamini et al.,2009.This can attract foreign investors.

\section{Inferential Statistics}

The study used inferential statistics (Pearson correlation and multiple linear regressions) to analyses the research objectives.

\section{Correlation Matrix}

The main objective of the study was to determine the effect of bank specific factors on financial performance of commercial banks in Kenya. The study used Pearson Correlation analysis to establish the kind of relationship that exists between the variables (bank specific factors, macro-economic factors and bank performance). Table 5 shows the Pearson correlation analysis of the relationship between bank specific factors, macro-economic factors and bank performance. Correlation matrix in appendix III shows the detailed correlation among the bank specific factors, macro-economic factors and bank performance.

Table 5: Pearson correlation analysis of the relationship between bank specific factors, macro-economic factors and bank performance

\begin{tabular}{lll|l}
\hline & & $\begin{array}{l}\text { Bank specific } \\
\text { factors }\end{array}$ & $\begin{array}{l}\text { Bank performance } \\
\text { (ROA) }\end{array}$ \\
\hline $\begin{array}{l}\text { Bank specific } \\
\text { factors }\end{array}$ & Pearson Correlation & 1 & \\
\cline { 2 - 4 } Bank performance & Sig. (2-tailed) & & \\
\cline { 2 - 4 } & Pearson Correlation & $0.847^{* *}$ & 1 \\
\hline
\end{tabular}

**. Correlation is significant at the 0.05 level (2-tailed).

Based on the results in table 5 the study revealed that there was a strong statistically significant relationship of ( $r$ $=0.847, \mathrm{p}<0.05)$ between bank specific factors and financial performance of commercial banks. Therefore, this confirms the relationship between bank specific factors and financial performance of commercial banks in Kenya. Multiple Regression Analysis 
The study used multiple linear regression analysis to determine the effect of bank specific factors and macroeconomic factors on financial performance of commercial banks in Kenya. The general objective of the study was to determine the effect of selected bank specific factors on the financial performance of listed commercial banks in Kenya. The bank specific factors include used in the study include: Capital adequacy, assets quality, management efficiency, liquidity management and risk management. The study used multiple linear regressions to determine the effect of bank specific factors on financial performance of listed commercial banks in Kenya.

Table 6: Multiple Regression Results Effect of Selected Bank Specific Factors on the Financial Performance of Commercial Banks in Kenya

\begin{tabular}{|c|c|c|c|c|c|c|c|c|c|c|}
\hline \multicolumn{11}{|c|}{ Model Summary } \\
\hline \multirow[t]{2}{*}{ Model } & & & & Std. Error & \multicolumn{5}{|c|}{ Change Statistics } & \\
\hline & $\mathrm{R}$ & $\begin{array}{c}\mathrm{R} \\
\text { Square }\end{array}$ & $\begin{array}{l}\text { Adjusted } \\
\text { R Square }\end{array}$ & Estimate & $\begin{array}{l}\text { Square } \\
\text { Change }\end{array}$ & $\begin{array}{c}\mathrm{F} \\
\text { Change }\end{array}$ & df1 & $\mathrm{df} 2$ & $\begin{array}{c}\text { Sig. F } \\
\text { Change }\end{array}$ & $\begin{array}{l}\text { Durbin- } \\
\text { Watson }\end{array}$ \\
\hline 1 & $0.984^{\mathrm{a}}$ & 0.968 & 0.937 & 3.76864 & 0.968 & 30.714 & 5 & 5 & 0.001 & 2.302 \\
\hline
\end{tabular}

a. Predictors: (Constant), Risk management, Liquidity management, capital adequacy, Asset quality,

Management efficiency

b. Dependent Variable: ROA

\begin{tabular}{llr|r|r|r|r}
\hline Model & \multicolumn{2}{c}{ ANOVA } \\
\hline \multirow{2}{*}{1} & Sum of Squares & Df & Mean Square & F & \multicolumn{1}{c}{ Sig. } \\
\cline { 2 - 8 } & Regression & 2181.079 & 5 & 436.216 & 30.714 & $0.001^{\text {b }}$ \\
\cline { 2 - 8 } & Residual & 71.013 & 5 & 14.203 & & \\
\cline { 2 - 8 } & Total & 2252.092 & 10 & & & \\
\hline
\end{tabular}

a. Dependent Variable: ROA

b. Predictors: (Constant), Risk management, Liquidity management, capital adequacy, Asset quality, Management efficiency

\begin{tabular}{|c|c|c|c|c|c|c|c|c|}
\hline \multicolumn{9}{|c|}{ Coefficients } \\
\hline \multirow{2}{*}{\multicolumn{2}{|c|}{ Model }} & \multicolumn{2}{|c|}{$\begin{array}{l}\text { Unstandardized } \\
\text { Coefficients }\end{array}$} & \multirow{2}{*}{$\begin{array}{c}\text { Standardized } \\
\text { Coefficients } \\
\text { Beta } \\
\end{array}$} & \multirow[b]{2}{*}{$\mathrm{t}$} & \multirow[b]{2}{*}{ Sig. } & \multicolumn{2}{|c|}{$\begin{array}{l}\text { Collinearity } \\
\text { Statistics }\end{array}$} \\
\hline & & $\mathrm{B}$ & Std. Error & & & & Tolerance & VIF \\
\hline 1 & (Constant) & 16.425 & 23.775 & & 6.909 & 0.001 & & \\
\hline & Capital adequacy & 33.412 & 108.224 & 0.286 & 3.087 & 0.027 & 0.733 & 1.364 \\
\hline & Asset quality & 91.219 & 22.458 & 0.382 & 4.062 & 0.010 & 0.714 & 1.401 \\
\hline & $\begin{array}{l}\text { Management } \\
\text { efficiency }\end{array}$ & 42.610 & 23.392 & 0.182 & 1.822 & 0.128 & 0.635 & 1.575 \\
\hline & Liquidity management & 9.424 & 40.506 & 0.020 & 0.233 & 0.825 & 0.847 & 1.180 \\
\hline & Risk management & 19.223 & 2.175 & 0.865 & 8.838 & 0.000 & 0.658 & 1.519 \\
\hline
\end{tabular}

a. Dependent Variable: ROA

Based on the results of the study in table 6, capital adequacy, asset quality, management efficiency, liquidity management and risk management) accounted for $96.8 \%$ financial performance of commercial banks in Kenya $\left(\mathrm{R}^{2}=0.968\right)$. From table 4.8 , the results show that there was no autocorrelation because the Durbin-Watson is 2.302 which is between 1.5 and 2.5 .

Based on ANOVA results in table 8, the level of significance was 0.001 with an F value of 30.714 which indicates a statistical significant relationship between bank specific factors and financial performance of listed commercial banks in Kenya because the $\mathrm{P}$ value which is 0.001 is less than $0.05(\mathrm{P}<0.05)$. Hence, the null hypothesis $(\mathrm{Ho} 1)$ which states that there is no significant effect of selected bank specific factors on financial performance of commercial banks in Kenya was rejected and alternative hypothesis which states that there is significant effect of selected bank specific factors on financial performance of commercial banks in Kenya is accepted because the results from table 4.8 shows that the level of significance was 0.001 with an F value of 30.714 which is less than $0.05(0.001<0.05)$ the significant level of the study. This confirms the effect of bank specific factors on financial of listed commercial banks. The results of the study conforms to the study done by Riaz and Mehar, (2013) on the impact of bank Specific and macroeconomic Indicators on the Profitability of Commercial banks where they found out that bank specific and macroeconomic indicators had a significant impact on Profitability of Commercial banks. 
The un-standardized beta coefficients in table 6 indicate that capital adequacy $(\beta=33.412, p<0.05)$, asset quality $(\beta=91.219, p<0.05)$ and Risk management $(\beta=19.223, p<0.05)$ were the robust predictors of financial performance of commercial banks in Kenya as compared to management efficiency $(\beta=42.610, p>0.05)$ and Liquidity management $(\beta=9.424, p>0.05)$ which were the least predictors of financial performance of commercial banks in Kenya. Therefore, the multiple regression results above generally indicate that capital adequacy, asset quality and risk management has a statistical positive significant effect on financial performance of commercial banks in Kenya. Moreover, the table 8 indicates that there is no multi-collinearity as shown by tolerance $(\mathrm{T}>0.2)$ and Variance Inflation Factor $(\mathrm{VIF}<10)$

Multiple Regression Model

$Y=a+\beta_{1} X_{1}+\beta_{2} X_{2}+\beta_{3} X_{3}+\beta_{4} X_{4}+\beta_{5} X_{5}+\varepsilon$

$Y=16.425+33.412 X_{1}+91.219 X_{2}+42.610 X_{3}+9.424 X_{4}+19.223 X_{5}+\varepsilon$

When there is a unit increase in capital adequacy, financial performance of commercial banks in Kenya will increase by 33.412 units, when there is a unit increase in asset quality, financial performance of commercial banks in Kenya will increase by 91.219 units, when there is a unit increase in management efficiency, financial performance of commercial banks in Kenya will increase by 42.610 units, when there is a unit increase in liquidity management, financial performance of commercial banks in Kenya will increase by 9.424 units and when there is a unit increase in risk management, financial performance of commercial banks in Kenya will increase by 19.223.

\section{Conclusion}

The general objective of the study was to determine the effect of bank specific factors on the financial performance of commercial banks in Kenya. Based on the results, it was established that bank specific factors have a negative effect on financial performance of commercial banks in Kenya. Moreover, discretely capital adequacy, management efficiency and liquidity management variables did not significantly affect financial performance of listed commercial banks. Comparatively while asset quality and risk management significantly affects the financial performance of listed commercial banks in Kenya

\section{Recommendations}

As indicated in the conclusion, that bank specific factors affect the financial performance of commercial banks in Kenya it is therefore necessary that government with aid of CBK and public financial institutions should come up with policies that protect the commercial banks from the negative effect of such factors in order to improve their financial performance.

From the study, banks specific factors like capital adequacy and asset quality significantly influence the financial performance of commercial banks in Kenya. This hints to the recommendation that the bank managers in financial institutions like listed commercial banks in Kenya have the main responsibility to hold enough capital and assets as they are the enhancers of financial performance. It is also important that commercial banks should be responsive to the negative effect of bank specific factors and constantly changing requirements of financial sector in order to improve and their financial performance.

The study focused on financial performance of listed commercial banks in Kenya only. This limits the generalization of results. Similar studies need to be conducted in other none listed commercial banks in Kenya. This research selectively captured listed commercial banks in Kenya only. A further research can be done to capture other financial institutions to establish whether the findings will be the same based on macro-economic factors

\section{References}

Al-Tamimi, H., \& Hussein, A. (2010). Factors influencing performance of the UAE Islamic and conventional national banks.

Athanasoglou, P. P., Brissimis, S. N., \& Delis, M. D. (2008). Bank-specific, industry-specific and macroeconomic determinants of bank profitability. International Financial Markets Institutions \& Money, 18, 121-136.

Callen, (2008). Expectation in modern domestic market. USA.

Central Bank of Kenya (2008). Bank Supervision Annual Report, Kenya.

Central Bank of Kenya (2013). Licensed Commercial Banks and Mortgage Companies.

Chaplinska, A. (2012). Evaluation of the borrower's creditworthiness as an important condition for enhancing 
Dang, U. (2011). The CAMEL Rating System in Banking Supervision: a Case Study of Arcada University of Applied Sciences, International Business. International Journal of Economics and Financial Issues, Vol. 3, No. 1, 2013, 237-252.

Diamond, D. W., \& Rajan, R. G. (2000). Liquidity risk, liquidity creation, and financial fragility: A theory of banking. Journal of political Economy, 109(2), 287-327.

Fang et al., 2014; Fang, Y., Hasan, I., \& Marton, K. (2014). Institutional development and bank stability: Evidence from transition finance-institutions.

Felix Ayadi et al., 2008; Zhang et al., 2013) Richard, E., Chijoriga, M., Kaijage, E., Peterson, C., \& Bohman, H. (2008). Credit risk.

Fisher, I. (1933). The debt-deflation theory of great depressions. Econometrica: Journal of the Econometric Society, 337-357.

Flick, U. (2009). An Introduction to Quantitative Research (4 ed.). California: SAGE Publications. .

Groves, R. (2004). Survey Methodology.Califonia: SAGE Publications.

Hassan, Kabir and Bashir, M. Abdel-Hameed (2003), "Determinants of Islamic Banking Profitability", Proceedings of the ERF 10th Annual Conference, Marrakesh, Morocco, 16-18 December, 2003.

Ilhomovich, S.E. (2009). Factors affecting the performance of foreign banks in Malaysia: A thesis submitted to the fulfilment of the requirements for the degree Master of Science (Banking) College of Business (Finance and Banking.)

Khrawish, A., \& Siam, Z., (2011). Determinants of Islamic Banks Financial performance: Evidence.

Khrawish, H.A. (2011) Determinants of Commercial Banks Profitability: Evidence from Jordan. International Research Journal of Finance and Economics, 5(5), 19-45 (Hassan and Bashir. 2003). Furthermore, Rivard and Thomas (1997).

Kosmidou, K., Tanna, S., \& Pasiouras, F. (2005). Determinants of profitability of domestic UK commercial banks: panel evidence from the period 1995-2002. Paper presented at the Money Macro and Finance (MMF) Research Group Conference.

Mugenda, O., \& Mugenda, A. (2003). Research methods: Quantitative and Qualitative methods. Revised in Nairobi.

Murerwa, C. B. (2015). Determinants of banks' financial performance in developing economies: evidence from Kenyan commercial banks (Doctoral dissertation, United States International University-Africa).

Olweny, T., Shipho, T.M. (2011) Effects of Banking Sectoral Factors On the Profitability of Commercial Banks in Kenya. Economics and Finance Review, 1(5), 1-30. On the

Ongore, V. O., \& Kusa, G. B. (2013). Determinants of financial performance of commercial banks in Kenya. International journal of economics and financial issues, 3(1), 237-252.

Ongore, V. O., \& Kusa, G. B. (2013). Determinants of financial performance of commercial banks in Kenya. International Journal of Economics and Financial Issues, 3(1), 237.

Said, R.M., \& Tumin, M. H. (2011). Performance and Financial Ratios of Commercial Banks in Malaysia and China.

Samad, A. (2004). Financial performance of Interest Free Islamic Banks vis-à-vis Interest-Based Conventional Banks of Bahrain. IIUM Journal of Economics and Management, 12 (2), 1-25.

Sangmi \& Nazir 2010. Analyzing Financial Performance of Commercial Banks in India: Application of CAMEL Model. Vol. 4 (1), 40-55

Shaher, T.A., Kasawneh, O. dan Salem, R. 2011. The Major Factors that Affect Banks' Performance in Middle Eastern Countries. Journal of Money, Investment and Banking, Vo

Sologoub, D. (2006). The determinants of Bank Interest Margins and Profitability: studies. College of Banking\&Financial studies, 83-94 